\title{
A Review of Domestic Socio-economic Barriers on Hydroelectricity Trading in Nepal
}

\author{
Laxman Thapa ${ }^{1}$, Ram Chandra Bhandari ${ }^{2}$ \\ ${ }^{1,2} \mathrm{Ph} . \mathrm{D}$ Schloar \\ ${ }^{1}$ Pokhara University \\ ${ }^{2}$ Prince of Songkla University (PSU), Khohong Haityai, Thailad
}

\begin{abstract}
Nepal is a Himalayan country that has surplus potential in hydropower generation. It lies among the largely populated countries such as India, China, Bangladesh and Pakistan. Nepal can be a country to fulfill its demand. However, for a few decades, Nepal has been suffering from domestic power shortages. This review study holds attention to intrinsic developmental barriers that stem from the domestic power supply, internal governance systems, and indigenous societal sensitivity. The barrier behind the unavailability of Nepal to export electric power is its insufficient production which is dragged by: energy treading policies, technical, environmental, economical, and financial factors, political and regulatory barriers, social and cultural barriers.
\end{abstract}

Keywords: Renewable Energy, Hydroelectricity, Hydropower, Nepal

\section{Introduction}

Hydropower is a clean, renewable energy source that is widely available around the world. The main source of hydropower is water, Because of the existence of steep mountains and the high Himalayas, climate diversity, and the country's geographical state, Nepal has huge potential to produce hydroelectricity. The annual precipitation ranges from 250 to $5200 \mathrm{~mm}$, with an average of $1770 \mathrm{~mm}$. The average water output from Nepal's rivers is around $222 \mathrm{~m}^{3} / \mathrm{s}$, with the snow-fed melting river alone accounting for roughly $4930 \mathrm{~m}^{3} / \mathrm{s}$ (1). Nepal has an estimated hydropower capacity of 83,000 MW, of which 43,000 MW is commercially viable (2). Precipitation from December 2019 to February 2020 and December 2020 to February 2021 (3).
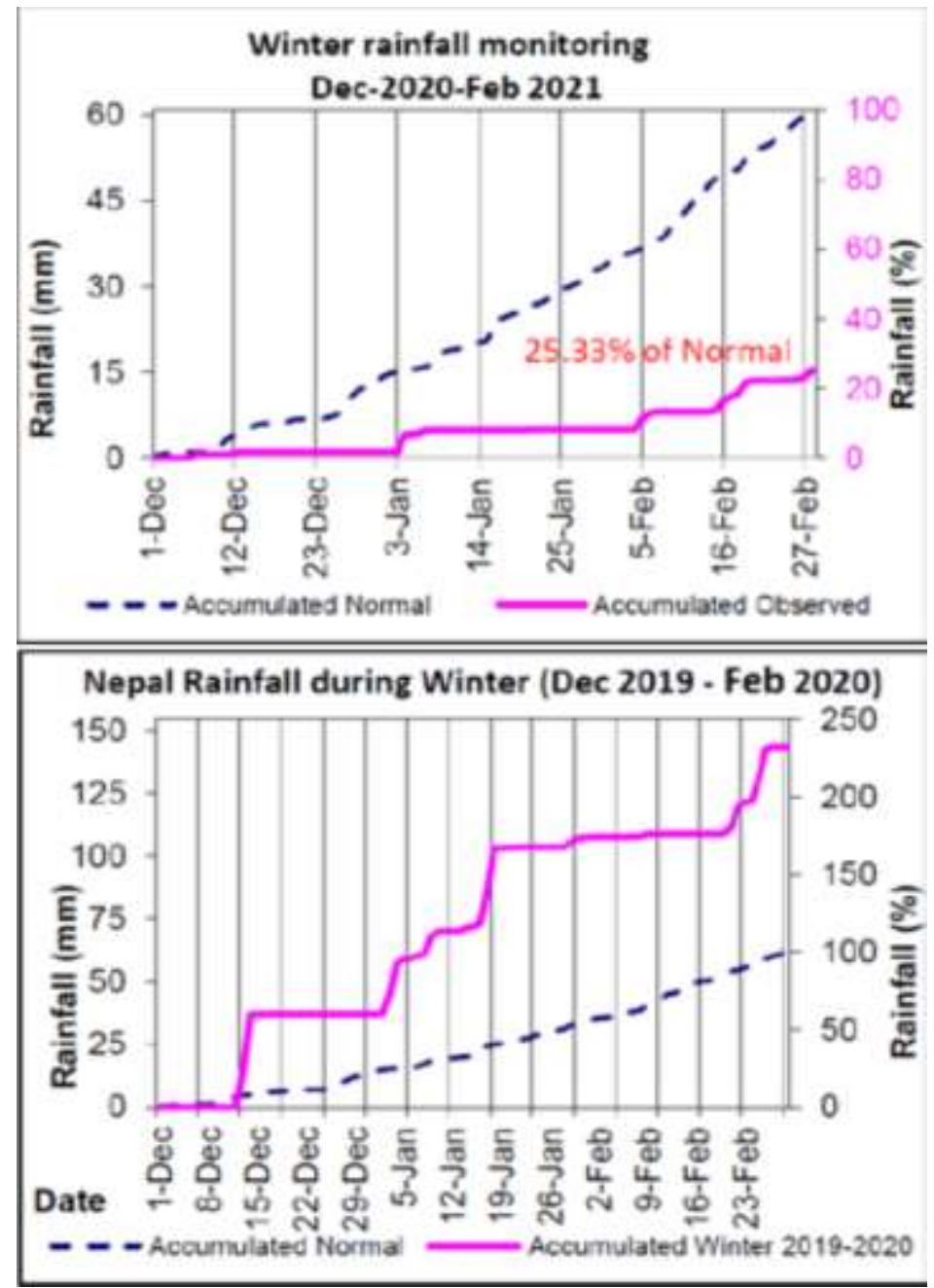


\section{History and Present Scenario of Hydro-Electricity in Nepal}

The world's first hydropower used to power a single bulb England in 1878 A.D. The first commercial production was done in Wisconsin, in USA. Nepal have a great history on the first installation of hydroelectricity in the South Asian region . In 1911 A.D., Pharping Hydropower Plant with the production of $500 \mathrm{~kW}$ of electricity was started. The next hydropower plant was built in 1934 with $600 \mathrm{kw}$ followed by Panauti $2.4 \mathrm{Mw}$ in 1965 A.D. (1). Between 1911 to 2020 A.D., Nepal had hardly exploited 2\% of hydroelectric power due to the geographical location of potential sites. Specially, Nepal needs technical and financial support to construct all these hydropower projects (4).

\section{Method}

This study is mainly based on a review of various analytical articles of Nepal government officials, World Bank, Asian Development Bank (5), Nepal's policy and strength plan documents, and Nepal Electric Authority (NEA) published in different media at different dates. In Nepal, the production of hydroelectricity is very slow in pace and only focuses on smaller capacities (4).

The main factors affecting the slower down in the production of hydroelectricity in Nepal are -Technical and environmental barriers, Economical and financial barriers, Political and regulatory barriers, and Social and cultural barriers (6).

\section{Results and Discussion}

\section{Domestic Power Supply}

Since 1990, few large hydropower projects are focused to export energy to India. But, Nepalese sentiments are in opposite. For instance, the West Hydropower Project had a capacity of $750 \mathrm{MW}$ designed with a storage system and was going to invest by a private Austrian developer (7). In that project, there was no electrical access to Nepalese. Later on, the project was reformed and got access to domestic uses also. A similar case was also reported for Arun III hydroelectric project. The Arun III hydroelectric project was halted due to misleading the local people about antagonistic sympathy towards India. But there was fear of scarcity of electricity in domestic supply. Finally, local people and the project got midpoint and the project was forwarded (8). The Arun III project was further ventured by the number of compliance issues with the World Bank's rules and procedures. The World Bank eventually decided to withdraw its funding. Similarly, financing for the West Seti project was also withdrawn by the ADB.

Many research data show that still, Nepal is not able to the rural area into its main grid system. For example, The gridconnected electrification ratios are $97 \%$ for Bhutan and 53\% for Nepal. Thus, Nepal's grid connection to households still covers only half of all households; one-third of the electrified households are on an off-grid basis, and one out of our households in Nepal has no access to electricity (4).

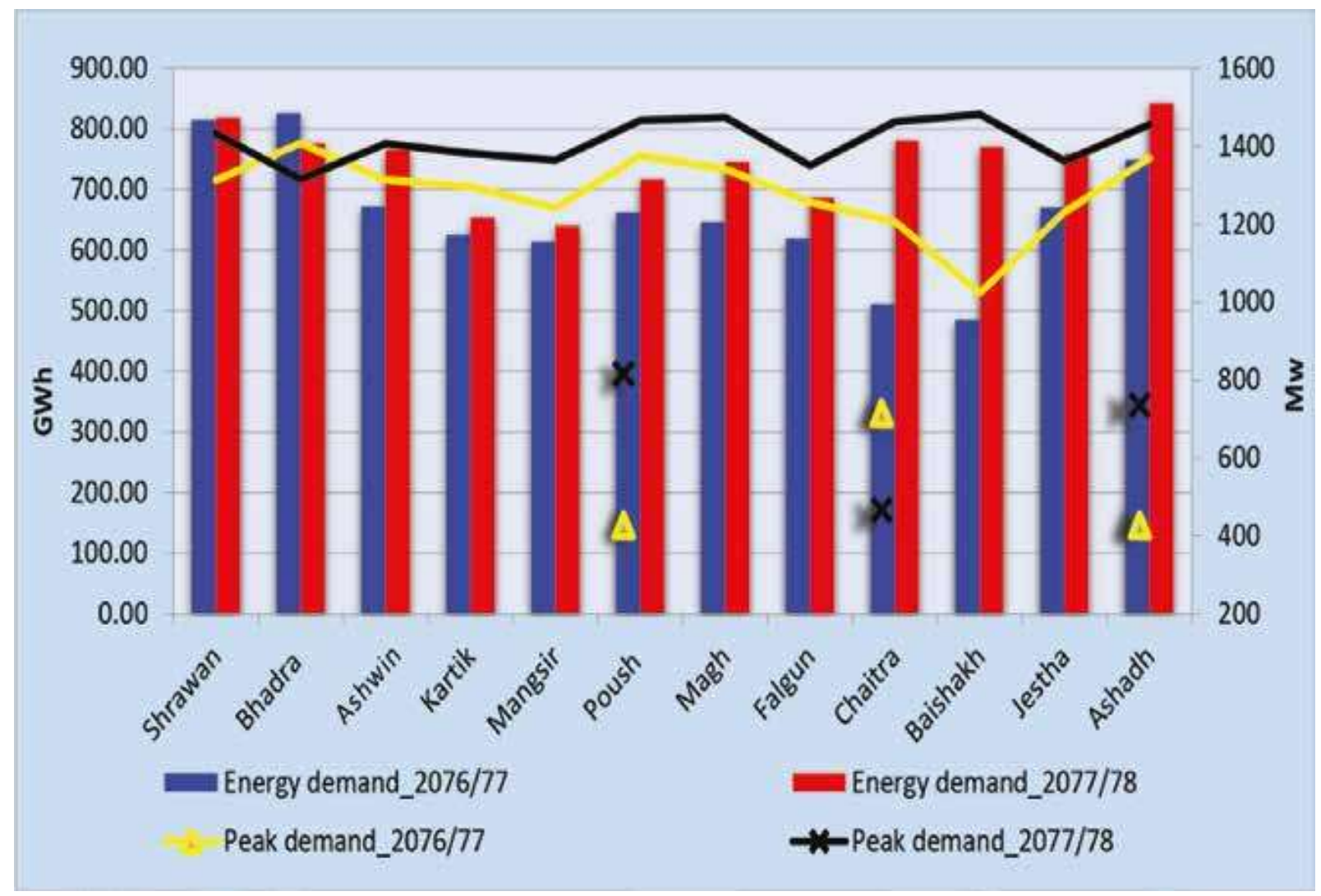

Figure 1: Demand and Supply of Hydropower in Nepal - 2076-2078 (3). 


\begin{tabular}{|l|l|l|l|}
\hline 1 & $\begin{array}{l}\text { Annual Peak } \\
\text { Demand }\end{array}$ & $\begin{array}{l}1481.85 \\
\mathrm{MW}\end{array}$ & $1 / 13 / 2078$ \\
\hline 2 & $\begin{array}{l}\text { Annual Energy } \\
\text { Demand }\end{array}$ & $\begin{array}{l}8960.31 \\
\mathrm{GWh}\end{array}$ & \\
\hline 3 & $\begin{array}{l}\text { Annual Load } \\
\text { Factor }\end{array}$ & $69 \%$ & \\
\hline 4 & $\begin{array}{l}\text { Total export } \\
\text { Energy }\end{array}$ & $\begin{array}{l}32.38 \\
\mathrm{GWh}\end{array}$ & \\
\hline 5 & $\begin{array}{l}\text { The maximum } \\
\text { Energy demand } \\
\text { of the Day }\end{array}$ & $\begin{array}{l}30.53 \\
\mathrm{GWh}\end{array}$ & $1 / 30 / 2078$ \\
\hline & $\begin{array}{l}\text { The maximum } \\
\text { power } \\
\text { imported in a } \\
\text { Day }\end{array}$ & $\begin{array}{l}846.74 \\
\mathrm{MW}\end{array}$ & $1 / 14 / 2078$ \\
\hline 7 & $\begin{array}{l}\text { The maximum } \\
\text { Energy import } \\
\text { of the Day }\end{array}$ & $\begin{array}{l}18.30 \\
\mathrm{GWh}\end{array}$ & $1 / 15 / 2078$ \\
\hline
\end{tabular}

Figure 2: Demand and Supply of Hydropower in Nepal 2076 -2078 (3)

\section{Social and Cultural Barriers}

The hydropower project is always associated with society whether for its use of or for its both positive impact and negative impacts (9). During the production of hydroelectricity, society should accept both pros and cons.

For instance, during the construction of Kali Gandaki, about 217 houses with the acquisition of 208.7 hectares were lost. Similarly, in the case of Middle Marsayandi, 3833.0 hectares of land and 379 trees were lost (8). Sometimes, large numbers of the family have to resettle at another place which may cause a direct impact on their culture. On the other hand, downstream, there is a change in lifestyle because of the depletion of groundwater and loss of economic opportunities (10). The resettlement means there is demolition of an old building and construction of a new one. The new structure may not include the customs, traditional architect, and other cultural norms.

In the social aspect, during transmission of electric lines, sometimes people demand things and large capitals. If their demand does not fulfill, indigenous people make protest, and eventually it creates very agitating social and political environments. Local communities are empowered with knowledge are emboldened to demand things.

It has even been reported that people move into designated project areas riot other initiation so they can demand money as compensation. Another dimension is opposition to community relocation, which has to occur for projects above small and large projects.

\section{Domestic Politics and Sector Reforms}

Initially, Nepal was a Hindu kingdom but after 2006 A.D., it becomes a Federal Republic country. From the beginning of hydroelectricity in Nepal, the political situation and governments is unstable. Since 1990, there have been more than 30 governments. In the meantime, during this period, Nepal had experienced Maoist insurgency so-called Civil War that lasted 11 years, from 1996 to 2000 (11).

In 2015, there was a huge earthquake which also slowed-down the production of electricity. The Nepali coalition governments tend to go for political power balancing arrangements, which undermine confidence and delay economic reforms (11). Thus, political instability and weak governance systems have very negative effects on the business and investment climate (12).

According to the World Bank assisted survey on hydropower development in Nepal, (BPI, 2009, Nepal) the barrier to hydropower development was an unstable political situation, followed by a lack of institutional capacity, such as rigorous development plans and coordination on hydropower and transmission. The volatile political situation and unstable governments make lacking on their internal decision-making, planning, and implementation processes in the energy-producing sector as well as in institutional reforms (4).

For instance, in the 2000s, the Bhutanese government changed a series of sectoral re-defined, which included the issuance of the sector's activities, the creation of the sector's regulations and definition of the role of a regulator, institutional unbundling to segregate the power generation business from transmission and distribution operations, and a private participation policy.

On the other hand, Nepal has been debating similar measures for more than a decade. The Nepal Electricity Authority (13) continues to be vertically declined as it has been since 1985, and its financial performance is not satisfactory. The viscous dragging factors can be summarized by the following diagram. 


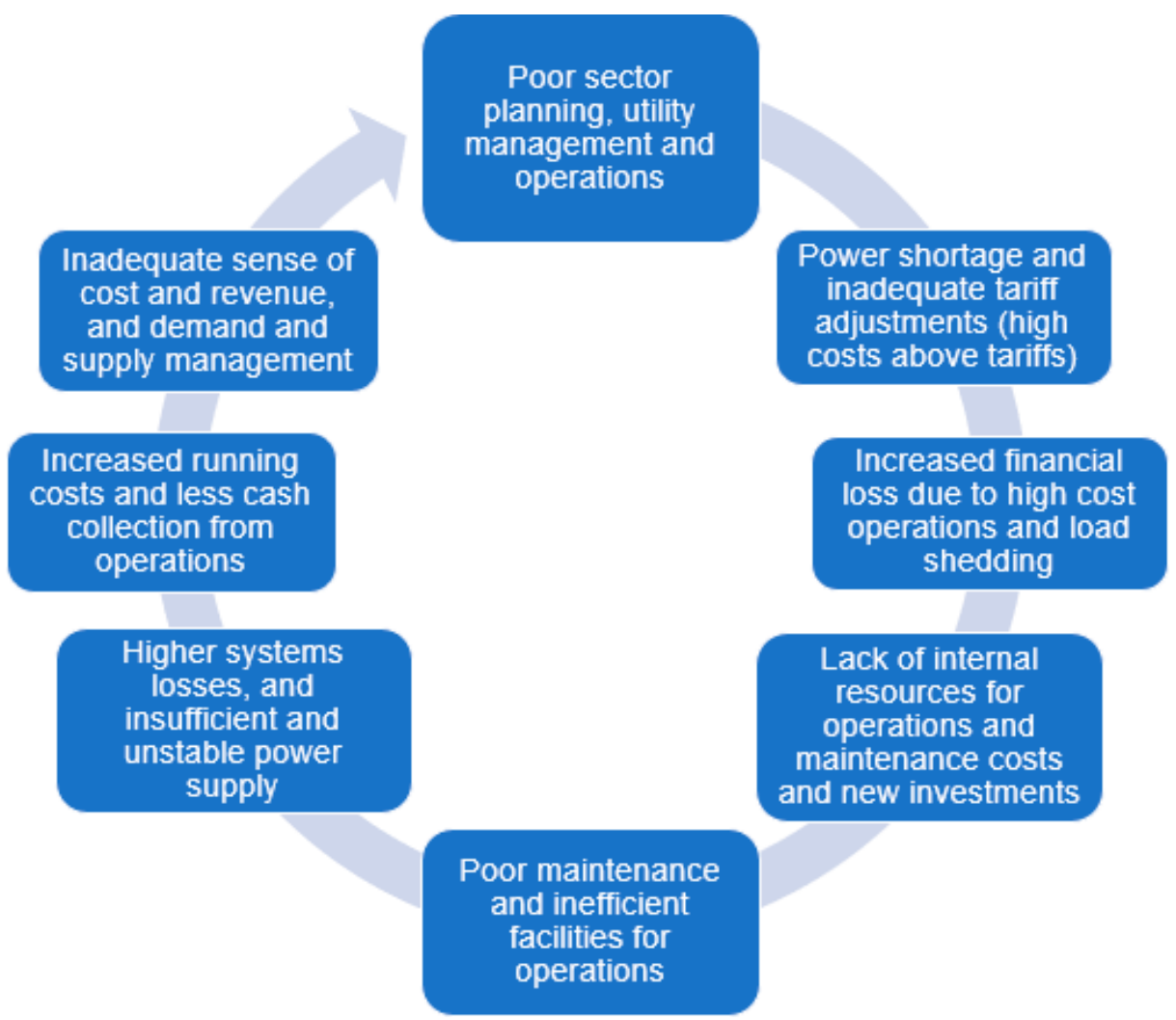

Figure 3: Nepal's vicious circle of inefficient sector planning, management, and operation

Source: (4)

\section{Societal Environmental and Social Sensitivities}

Hydropower production means perturbation on the natural system that has an environmental impact. The hydropower projects are always related to social and environmental sensitivity and required careful handling. Especially, dam projects trigger socio-economic impact on the lives of people dwelling in the project area nearby it (9). In hydropower, the project structural size and catchment area have largely impacted the watershed (4). The various civil works such as water reservoir, dam constructing tailrace tunnel and side road construction are main causes of deforestation and some other natural hazard may occur in project side. The research group reported that Nepal's energy is dominated by fuel wood (68\%), agricultural waste (15\%), animal dung (8\%), and imported fossil fuel (8\%), and suggested that access to grid-connected power for nearly half of Nepal's population should be improved by exploiting hydropower resources (14). After electrification in the rural area, the proportion of deforestation is decreased.

Another example is in Tanahun hydropower project has to be cut down about 1,600,000 trees. To maintain the green forest nearby the affected area for the loss of trees, Nepal's regulations determine the replacement of the affected trees at a ratio of 1:25 (5). This requirement significantly increased the project's environmental management costs for tree plantations. In Nepal, only deforestation is supposed a negative environmental impact. On the other hand, there are multiple environmental factors such as water degradation, groundwater depletion, scarcity of water, and loss of economical opportunities (10).

The reservoir was developed only for hydropower generation, but in Nepal, there have been domestic requests for and debates over multipurpose dam type projects, which can typically cover power generation, irrigation, and flood control to make other potential stakeholders amenable. The multipurpose projects may carry an array of benefits among the stakeholders, the project facilities can be larger, as well as their corresponding costs and safeguard impacts. Sometimes such project also has large social impacts. Its resettlement plan estimate has a very large value (5).

Sometimes different ethnic groups and societies have conflicts regarding water resources and electrification. According to USAID (ARD, USA, 2006) reports after Maoist insurgency had been indirectly rooted in conflicts due to environmental degradation, resource scarcity, social inequality, and concomitant limited access to natural resources and services, coupled with limited economic opportunities outside urban areas, widespread rural poverty, and the Nepali government's weak capacity to control these matters.

Most of the hydro project sides are in big rivers and open valleys which has affected large live stoke and private properties. Consequently, affected groups have bad feelings about hydropower projects. But the same case does not happen in another Himalayan country Bhutan (8). 


\section{Economic and Financial Barriers}

Hydropower installation means setting up complex infrastructure. To set hydropower, requires a large amount of money, a good agreement, and cooperation of multiple layers of government and several institutions (8).

The cost requires in the production of storages type of hydropower is about Nrs. 150,000 to 200,000/ kilowatt. The fundamental constrain to developing hydropower in Nepal is poverty. It has one of the lowest per capita incomes in the world that is about less than US\$1034 per year (15), and about one-third of people live below the national poverty line. In such very poor financial condition is not able to upgrade their grid, to electrify not only remote hilly regions but also plain areas (10). Nepal's current financial status may not be sufficient to meet its needs. As a result, in addition to the NEA, additional private sector and overseas investors should be encouraged to provide the financial demand for hydropower development. The NEA's poor financial condition and high power tariffs have made it difficult to attract FDI (foreign direct investment) and contribute to the nation's electrical needs (16).

To increase the financial condition at hydropower production not only did NEA put forward more ideas but also the private sector and foreign investment should be introduced.

\section{Conclusion:}

- Dam construction and water reservoir causes depletion of ground water and loss of economic opportunities.

- $\quad$ Re-settlement of people shifted form affected area is not acceptable to the people as they are fear of customs traditional architect, traditions and cultural shifts and avoidances.

- At line transmission, the presence of overhead line in an individual's land decreases the value of people's land so they create hurdles in the process of fitting overhead transmission and also demand high compulsion.

- In last decades Nepal has suffering from paucity of electricity so people has very sensitive in domestic demands than export of electricity.

- The occupancy of land by larger reservoir is not acceptable to the local people and hence they resist the projects existence because of their oerives on property, crops and life existence.

- Storage of the water may cause harm on current of water in the same cannels and streams so lower stream part lead the scarcity of water eventually people migrant their settlement.

- Dam construction for water storage nearby community creates fear of flood on them.

- Unstable government of Nepal causes the lack of long term policy ownership is created by governments as policy of existing government regarding hydropower and plans may not be easily handed over to the upcoming government.

- Different earth hazard imbalances such as earthquake, heavy flood, and people's moments and strikes regarding the governments' activities and governments attention to settle the strikes and disputes causes delay on policy formulation , rectification and implementation.

- Poor Financial condition of people one third of people are below the national poverty line .

- Difficulties for upgrading it grid due to poor financial condition.

- Geographical locations barriers to spread the transmission of the energy in remote area.

- Lack of financial efficiency for the large construction.

\section{Acknowledgment}

The authors are grateful for the data provided by the Nepal Electricity Authority (NEA) and the Asian Development Bank (ADB). The authors are also grateful to Helmut Duerrast of Prince Sonkla University (PSU), Thailand, Pokhara University Nepal and Dr. Saroj Gawali.

\section{References}

[1] Sharma R H, Awal R. Hydropower development in Nepal. Renewable and Sustainable Energy Reviews. Vol. 21. 2013. p. 684-93

[2] Ogino K, Nakayama M, Sasaki D. Domestic Socioeconomic Barriers to Hydropower Trading: Evidence from Bhutan and Nepal. Sustainability. 2019. Apr 7. 11 (7). 2062

[3] ADB. ADB to Finance Second Hydropower Plant PPP in Bhutan. 2014. 1-6. https://www.adb.org/news/adb-financesecond-hydropower-plant-ppp-bhutan

[4] Sovacool B K. Rejecting renewables: The socio-technical impediments to renewable electricity in the United States. Energy Policy. 2009. 37 (11). 4500-13. DOI: 10.1016/j.enpol.2009.05.073

[5] Koirala S, Jung M, Reichstein M, de Graaf IEM, Camps-Valls G, Ichii K, et al. Global distribution of groundwatervegetation spatial covariation. Geophys Res Lett. 2017. 44 (9). 4134-42

[6] Sundar N. Unpacking the "Joint" in Joint Forest Management. Dev Change. 2000. 31 (1). 255-79

[7] Ogino K, Dash S K, Nakayama M. Change to hydropower development in Bhutan and Nepal. Energy Sustain Dev. 2019. 50. 1-17. DOI: $10.1016 /$ j.esd.2019.02.005

[8] Bird G, Rowlands D. The Effect of IMF Programmes on Economic Growth in Low Income Countries: An Empirical Analysis. J Dev Stud. 2017. 53 (12). 2179-96. DOI: 10.1080/00220388.2017.1279734

[9] Singh A, Jamasb T, Nepal R, Toman M. Electricity cooperation in South Asia: Barriers to cross-border trade. Energy Policy. 2018. 120. 741-8. DOI: $10.1016 /$ j.enpol.2017.12.048

[10] NEA (Nepal Electricity Authority). A Year In Review - Fiscal Year 2012/2013. 2012. 1-120. Available from: 
www.nea.org.np

[11] Schulz C, Saklani U. The future of hydropower development in Nepal: Views from the private sector. Renew Energy. 2021 Dec 1. 179. 1578-88

[12] Sovacool B K, Dhakal S, Gippner O, Bambawale M J. Halting hydro: A review of the socio-technical barriers to hydroelectric power plants in Nepal. Energy. 2011. 36 (5). 3468-76 